\title{
LARGE INTRAORAL MAXILLARY HAEMANGIOMA IN A NEWLY BORN INFANT
}

\author{
Shadia Abdelhameed Elsayed ${ }^{1}$, Heba Atwa², Alaa Abdelqader Altaweel ${ }^{3}$, Fatma Khalifa4
}

${ }_{1}^{1}$ Associate Professor, Department of Oral and Maxillofacial Surgery, Taibah University Dental College \& Hospital, Al-Madinah AlMunawwrah, Saudi Arabia. And Assistant Professor, Department of Oral and Maxillofacial Surgery, Faculty of Dental Medicine, AlAzhar University (Girls Branch), Cairo, Egypt.

${ }^{2}$ Lecturer Department of General Surgery, Faculty of Medicine for Girls. Al-Azhar University in Cairo, Egypt.

${ }^{3}$ Assistant Professor of Oral \& Maxillofacial Surgery, Faculty of Dental Medicine, Al-Azhar University for Boys, Cairo, Egypt. Associate Professor of Oral \& Maxillofacial Surgery, Alfarabi Private College for Dentistry and Nursing, Jeddah, Kingdom of Saudi Arabia. ${ }^{4}$ Assistant Professor, Department of Oral and Maxillofacial Surgery, Faculty of Dental Medicine, Al-Azhar University (Girls Branch), Cairo, Egypt.

HOW TO CITE THIS ARTICLE: Elsayed SA, Atwa H, Altaweel AA, et al. Large intraoral maxillary haemangioma in a newly born infant. J. Evolution Med. Dent. Sci. 2019;8(12):960-961, DOI: 10.14260/jemds/2019/214

\section{PRESENTATION OF CASE}

Intraoral Haemangioma in newly born infants is rare worldwide. Here we report a new case of a large haemangioma mass extruding outside the oral cavity, present at the time of natural child birth, in January 2016, at AlZahraa University Hospital in Egypt. A new born female infant had a large lesion bulging from the oral cavity. It was soft sessile, filling the whole mouth of the baby and disturbing normal sucking and feeding process. The obstetrician immediately requested a consultation with an oral and maxillofacial surgeon.

History of the mother's pregnancy was normal without any abnormal symptoms. Even the routine ultrasound examination during pregnancy didn't indicate the presence of this lesion. In the present description, we report the first case of this condition which is not seen in our institute before.

On clinical examination of this case, the lesion was $3.2 \mathrm{~cm}$ in diameter and was soft with non-ulcerated thin covering mucosa. It was mobile not fixed and 'no any other abnormalities were detected on the physical examination of the patient (Fig. 1). Upper lip soft tissue examination by superficial probe revealed a well-circumscribed, bear shaped, thin-walled, solid, and soft tissue lesion with homogenous iso- to hypo- echoic echotexture. It is measuring about $33 \mathrm{x}$ $13 \mathrm{~mm}$ in AP \& craniocaudal diameters. It showed minimal colour filing on Doppler examination. It shows no sonographic evidence of calcification, septation or cystic changes inside. No evidence of deep tissue invasion.

\section{DIFFERENTIAL DIAGNOSIS}

Intraoral newborn lesions are rare conditions especially if it is large in size. Soft tissue swelling in the newly born infants has low incidence among our population, although various single or/and multiple lesions had been reported in other populations as congenital epulis of the newborn or congenital teratoma.

'Financial or Other Competing Interest': None.

Submission 08-02-2019, Peer Review 10-03-2019,

Acceptance 16-03-2019, Published 25-03-2019.

Corresponding Author:

Shadia Abdelhameed Elsayed

Associate Professor of Oral \& Maxillofacial Surgery,

College of Dentistry, Taibah University,

Al-Madinah Al-Munawarrah, KSA

Researcher ID: E-5446-2018.

E-mail: shadiaelsayed@azhar.edu.eg

DOI: $10.14260 /$ jemds $/ 2019 / 214$

\section{(c) $(\mathrm{P})($}

The female neonate is most likely to have a higher prevalence rate of these conditions such as melanotic neuroectodermal tumour of infancy or vascular malformations and haemangiomas. $(1,2,3,4)$

Moreover, diagnosis is difficult clinically. Differential diagnosis may include other diseases as alveolar cyst of the newborn,(5) mucous extravasation lesions(6) and other developmental oro-antral lesions. In addition, fungal, viral and bacterial lesions have also been reported.(7)

Clinical finding of this case study suggested soft tissue lesion with a vascular element, apparently of benign nature, and so further correlation and evaluation after the decision of complete excisional biopsy was done.

Although, Haemangioma in newborns had been reported in various parts of the body as gastric, bladder, intracranial, pulmonary, cardio-atrial, umbilical cord, hepatic, cutaneous, retino-cavernous, and scalp haemangioma. Moreover, in the maxillofacial region it has been reported in zygoma, lip and lingual regions. $(1,3,5,8,9)$

\section{PATHOLOGICAL DISCUSSION}

Cytopathological report of the FNAB of the swelling protruded from the upper jaw- Microscopically, cytological examination of the aspirated smears revealed the presence of haemorrhagic smears with few endothelial cells. No inflammatory or neoplastic cells could be detected. Negative for malignancy. On histopathological examination capillary haemangioma was confirmed.

Infantile Haemangioma is a rapidly growing benign vascular tumour in which one third or approximately $30 \%$ of the tumour is present at birth. Capillary haemangioma is a slow flow vascular lesion which usually doesn't cause underneath bone destruction.(1,2)

Incidence rate of infantile haemangioma ranges between $4 \%$ to $10 \%$ and increases in association with other congenital deformities or other birth defects. $(2,3)$ It occurs 2.4 times more in females than male infants and $60 \%$ of this anomaly occurred in the maxillofacial region.(2)

\section{DISCUSSION OF MANAGEMENT}

Management of newly born haemangioma involved a wide range of treatment options starting from observation for spontaneous regression of the lesion and conservative propranolol treatment to surgical intervention with either conventional resection or with adjunctive laser therapy.(7,10)

Immediately, the decision was taken to remove the lesion entirely under local anaesthesia, after performing full clinical 
examination, ultrasound, fine needle aspiration biopsy, (Fig. 2) and obtaining the consent of the patient's parents.

Haemostasis was obtained and resorbable suturing (4-0 Vicryl) was secured on the bed site. The family was given instructions and follow up scheduled every month for the first 2 years.

Rapid surgical excision was mandatory in the present case as it was causing obstruction to the oral cavity, unlike in other vascular malformation anomalies which require more aggressive excision with safety bony margin to avoid recurrence.(11) Follow up of this case was uneventful and no recurrence was detected.

\section{FINAL DIAGNOSIS}

Capillary Haemangioma
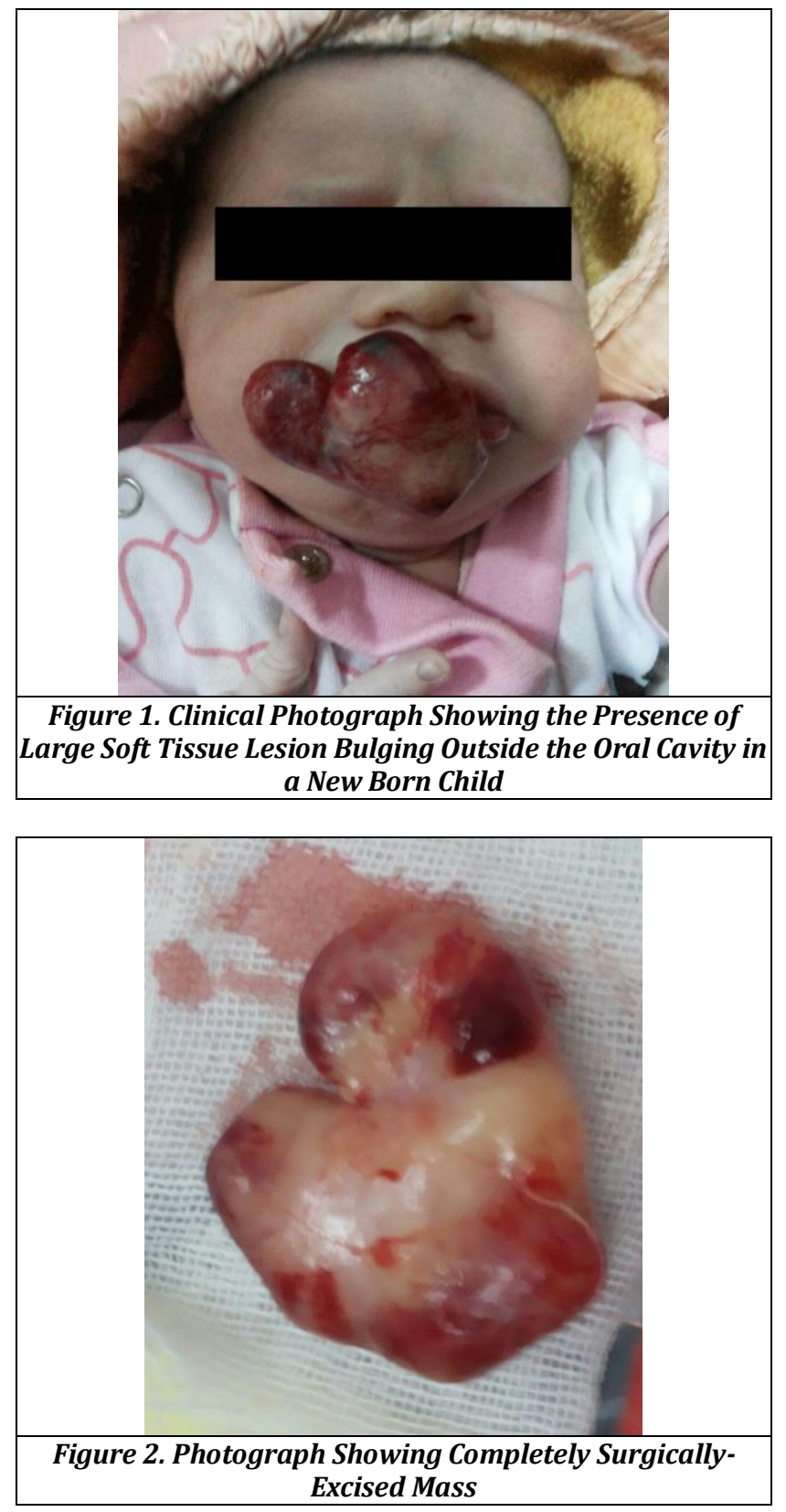

\section{REFERENCES}

[1] Leung AK, Rafaat M. Benign Neonatal hemangiomatosis. Pediatr Dermatol 2003;20(2):1613.

[2] Abramowicz S, Padwa BL. Vascular anomalies in children. Oral Maxillofac Surg Clin North Am 2012;24(3):443-55. http://dx.doi.org/10.1016/j.coms.2012.05.001

[3] Léauté-Labrèze C, Harper JI, Hoeger PH. Infantile haemangioma. Lancet 2017;390(10089):85-94.

[4] Freudenberger S, Díaz SMA, Bravo JM, et al. Intraoral findings and other developmental conditions in Mexican neonates. J Dent Child (Chic) 2008;75(3):2806. http://www.ncbi.nlm.nih.gov/pubmed/19040815

[5] Viswanathan R, Bharath KP. Alveolar cyst of the newborn: a case report. Arch Orofac Sci 2012;7(2):857.

[6] Gatti AF, Moreti MM, Cardoso SV, et al. Mucous extravasation phenomenon in newborn babies: report of two cases. Int J Pediatr Dent 2001;11(1):74-7.

[7] Maheshwari S, Thambiah LJ, Deepak V, et al. Role of trimolecular signaling system in bone pathologies. An expedition into the ambiguity of ghost cells Oral neonatal lesions role of myofibroblasts: a review. 2014;18:79-81.

[8] Van Es RJJ, Wittebol-Post D, Beemer FA. Oculodentodigital dysplasia with mandibular retrognathism and absence of syndactyly: a case report with a novel mutation in the Connexin 43 gene. Int J Oral Maxillofac Surg 2007;36(9):858-60.

[9] Diniz MB, Elisa GMA, Angela ZCC, et al. Congenital epulis: a rare benign tumor in the newborn. J Indian Soc Pedod Prev Dent 2010;28(3):230-3. http://www.jisppd.com/text.asp?2010/28/3/230/73 787

[10] Moussa SA, Elsayed M, Mansour S, et al. Melanotic neuroectodermal tumour of infancy: a report of two cases. Int J Surg Case Rep 2018;53:337-44. https://doi.org/10.1016/j.ijscr.2018.11.004

[11] Elsayed SA, Alahmady HH. Heamangioma in parotid gland encroaching on the temporomandibular joint: a case report. Tanta Dent J 2014;11(2):109-13. http://linkinghub.elsevier.com/retrieve/pii/S168785 741400033X 